\title{
THE ASSESSMENT OF THE LEVEL OF MANAGEMENT CONTROL STANDARDS COM- PLETION IN TREASURY SECTOR
}

\author{
Ewa KULIŃSKA*, Agnieszka DORNFELD** \\ The Opole University of Technology \\ *The Faculty of Economy and Management, Department of Marketing and Logistics \\ e-mail: e.kulinska@po.opole.pl \\ **The Treasury Control Office, Internal Auditor \\ e-mail:agdo@onet.eu
}

\begin{abstract}
This paper concerns the rules of the functioning of management control standards used in the Treasury Control Office. Its purpose is to present research results conducted in the years 2013-2014 in Polish Treasury Control Offices. Obtained results are the effect of applying author's model of the assessment of management control implementation. The research was conducted for management personnel and the rest of offices employees separately. Significant discrepancies between these two groups of respondents were indicated. Based on the results, the areas of deviation from expected level of management control standards were established and the areas where implementation of control mechanisms relying on increasing the supervision of board of directors over managers were indicated, providing permanent and efficient elements of managers supervision over subordinate employees and making purposes and tasks put on the Treasury Control Office for given year more precise and familiarization of employees and carrying out trainings and series of other corrective measures.
\end{abstract}

Keywords: management control, Treasury Control Office, risk factors, internal environment, purposes and risk management, control mechanisms, information and communication, monitoring and assessment.

\section{1}

\section{Introduction}

In the contemporary demanding and dynamic work environment, every managing person "shall" incur the risk of undertaken decisions. Each business decision is connected with measurable risk that must not be understood pejoratively. The risk level in the decision-based process shall be supervised, and it is a subject of the management control.

It should be emphasized that without risk, there is no profit to great extent, and it is difficult to discuss the increase in the goodwill. Superior purpose of the management control is the protection and maximization of the entity value: its property, cash flow, operational capability, and the market share. The risk of functional disorder sometimes cannot be avoided or eliminated, sometimes it cannot be managed properly; however, it is necessary to take actions connected with the risk consciously not to add additional damage or cause a failure in achieving assumed purposes of entity.
Even professional and well-organized management control (conscious approach to the process, implementation of regulations connected with the problem, without its proper use) shall not cause entire elimination of hazard. It shall contribute to the fact that the assessment, comparison, and procedure criteria common for the whole organization shall exist (shall be implemented and organized) toward risk factors, even extremely different from areas of the entity operation. Besides, as a result of this approach, it shall be defined as simple dependencies between the efficiency of management control in the entity and the purposes achievement. Proper, thoughtful, and well-organized management control is the essence for hazards in reality. First of all, it prepares the entity if some hazards occur.

\section{Management control in the management sciences}

The process of the organization management, including the sector of public finances can be characterized 
into the following four phases: planning, organizing, leadership, and control (S. P. Robbins, D.A. DeCenzo, 2002, p. 32; R.W. Griffin, 1998, p. 36.). According to Art 68 Public Finance Law (Art. 68. 1.), ${ }^{1}$ department of public finance are obliged to conduct professional management based on management control.

Management control was effective on 1 January 2010 and elastically entering into mechanisms and standards of management sciences. There are generally action taken to provide the purposes and tasks completion in a way that is conform to the law applicable, effective, economic, and timely. It covers the management area, including the following: planning, organizing, leadership, and control.

The essence of management control and its genesis in management sciences is noticeable while comparing key elements of the theory of management sciences and standards of management control in departments of public finances (Announcement no. 23 Minister of Finance Dz. Urz. MF no. 15, item 84).

According to E. Nowak the risk management is defined as the process of verification if the operations of the department of public finance conforms to arrangements included in the operations plan and if the entity obtains assumed purposes. The management control is an element of control system of the entity operations that covers monitoring of the operations and is a base for taking corrective action that shall prevent against any irregularities in the future (E. Nowak, 2003, p. 266). According to B.R. Kuc, the control, as far as managerial function of leadership is concerned, is a set of actions which essence is collecting information and its purpose using the information for processes correction or behaviors of people who are controlled (B.R. Kuc, 2006, p. 145).

The management control according to the notations of the Act shall be identified with the term internal control, functioning in international standards. However, the definition of internal control coined by INTOSAI (The International Organization of Su-

\footnotetext{
${ }^{1}$ Management control in the entities of public finance sector is all the actions taken to provide the completion of purposes and tasks according to legal regulations, effectively, economically, and on time.
}

preme Audit Institutions) describes it as a tool for management used to obtain a rational reliability that management purposes are achieved. Internal control includes functional factors that are used by the management board to get national reliability that operation of the entity is directed to fulfill the mission. It is also helpful in conducting arranged, effective, ethical, economical, and efficient operations fulfilling obligations connected with the responsibility, conformity with laws and regulations on resources protection against the loss, improper use, and destruction. Internal control includes functional resources that are used by the management board to get the reliability from internal sources that processes for which they are responsible are run to minimize the probability of fraud, mistake, or uneconomic or ineffective practices (INTOSAI, 2000, p. 74).

Statutory definition of management control diverges significantly from classic model described earlier, meaning of "control" definition. It is a category that concerns the management process and connects elements of leadership and responsibility in a public sector (E. Chojna-Duch, 2011, p. 90). The management control in the department of public finance covers five sets of issues, that is, internal environment, goals and risk management, supervision mechanisms, monitoring, information and communication, and assessment. The catalog of goals in the management control is opened and requires determining by the manager of a department of public finance the additional purposes of the entity considering the character, subject of the operations, and conditions of functioning of managed entity (L. LipiecWarzecha, 2011).

The management control is defined as the action taken in the entity in order to provide the purposes and tasks completion. The Act does not indicate, however, what kind of action are concerned; it also does not define exemplary catalog of these tasks. The conceptualization of the catalog would be stymied or even impossible, because of defined understanding of the management control institution as actions directed for the tasks completion of definite and personalized entity of public finance. These action are various not only because of various subject of the operations of entities that form the sector 
of public finance or the amount of resources they have but even in single entity the goals and priority tasks can be different in the next budget years. The management controls hall cover such issues as determining proper structure of the entity, employing right personnel, analysis of chances and threats connected with tasks completion, implementation of proper procedures and supervising.

The management control assumes that the result of operations is possible to identify and compare with the established purposes and the fact that the information can be used to redirect the efforts to the areas of entity operations which are essential. For example: "measurable" means "rational" and, finally, it can be a term of the "quantification" of the question: whether planned event occurred or not (quantification "one" or "zero"). However, many activities both in private organizations and public ones obtain results in quality categories. How can we estimate results of army operations in a peace time, results of public relations department, results of managerial actions and personnel, results of education ministry? In these cases, only resources allocated in the activity can be measured; however, it does not include results (http://www.wneiz.pl/nauka _wneiz/frfu/53-2012/FRFU-53-11.pdf).

Basic function of the management control is the purposes and tasks completion of the entity according to the criteria described in the Act. Determining and achieving goals and tasks is of basic and individual character for every department of a sector of public finances. Does it fulfill the condition of individualization and appealing to purposes and tasks of the entity determined in the Act, that is, a base of its functioning? ${ }^{2}$ Tasks and purposes shall be defined on a sufficient level, not absolute, and according to the following rules:

- goals and tasks shall be defined clearly and at least in annual perspective,

\footnotetext{
2 That is, referring to the gmina (en. commune) referring to lawfully determined scope of tasks to which we include meeting needs of the community (Art. 7 paragraph. 1 u.s.g.) from tasks defined for completion of management control point of view, as too general and do not fulfill any function.
}

- goals shall meet the smart condition, that is, shall be specific, measurable, achievable, and relevant, timed $^{3}$,

- purposes and goals completion shall be monitored with indicated criteria,

- in superior entity or supervising entity, proper monitoring system of purposes and tasks completion for subordinate or supervised entities shall operate,

- performing the assessment of purposes and tasks completion considering the criterion of economy, effectiveness, and efficiency is recommended,

- determining purposes and tasks entities, organizational units, or people directly responsible for the completion and resources planned for the completion shall be determined,

- the possibility of indicating the purpose of existing entity in the form of short and synthetic description of the entity mission shall be considered.

While determining the purposes and tasks of the department of public finance, the same criteria shall be used, which form the standard in defining purposes in task-based financial scheme (Announcement no. 6 Minister of Finance Dz. Urz. MF no. 5, item 22), dictating to determine the purposes significantly and set in time precisely, clearly, in a consistent, measurable and realistic way. The purposes shall be determined for completion in every budget year and indicate starting measures, measures planned to be achieved, rules of monitoring the principles to achieve, and principles of recording of planes completion (K. Puchacz, 2009, p. 40).

\footnotetext{
${ }^{3}$ According to Art. 27 Ordinance of the Council (WE, EURATOM) no. 1605/2002 of 25 June 2002 concerning financial ordinance used for general budget of European Community (Dz.U. L 248 of 16.09 .2002 , p. 1), defined, measurable, achievable, proper and determined in time purposes shall be determined in all areas of operations covered in the budget. Achieving these purpose is to monitor with efficiency meters for each activity; however, the information are delivered to budget authority by a body that deals with the expenses. Budget resources are used according to the principle of proper management of finance, namely, acc. to economy, effectiveness and efficiency principles. The principle of economy means that the resources used by the entity to run its operations shall be available in due time, amount, and for best price. Using the effectiveness principle means striving for as good connection between used resources and achieved results as possible. The efficiency principle means achieving determined purposes and results.
} 
Determining purposes shall meet the condition of significance, that is, to cover the most important areas of the activity of public fund administrator (entity). The purpose is determined precisely and clearly, when it refers to basic, intentional result of tasks and subtasks completion, it is formulated clearly and providing unambiguous interpretation, contains the description of the matter or the state of affairs, which shall be the result of the task completion. Precisely and clearly defined purpose does not contain detailed and extensive definitions or technical abbreviations. The consistency means mutual compliance of purposes, without repeating among others the name, content, or ways of the intervention.

The condition of the measurability is fulfilled when the level of a purpose completion can be measured with the indicators. Assumed purpose considers the period in which it is performed. The term when the purpose can be completed is determined precisely, and the purpose that does not have time perspective is considered as unachievable. Realistic determination of the purpose means the consideration of risk factors of its completion at the planning phase. The purpose determined in this way shall oscillate around positive results of the task completion, not a minimum assuming the certainty of achieving the purpose. While determining the purposes, the progress, and development of results within the politics area shall be assumed, not only to strengthen as things stand in this field.

The management control in the department of public finance covers five groups of the issues, that is, internal environment, purposes and risk management, control mechanisms, information and communication, monitoring, and assessment. General purposes of management control defined in the Act are enumerated specifically, identified, and covered as follows:

- Conformity to the legal regulations and internal procedures, that is, the operation legality.

- Efficiency and effectiveness of operations.

- Credibility of reports concerning both financial issues (e.g., reports on the completion of collecting and dispensing public finance, reports on substantive activities of the entity).
- Resources protection (control mechanisms) by providing the access to entities only authorized personnel. In every entity, the principles of assets distribution shall be prepared as well as periodical control of resources with inventory method shall be made, and managing personnel and employees shall be entrusted with the responsibility for providing the protection and proper use of entity's resources.

- Observing and promoting the rules of ethical behavior (internal environment). Managing personnel and employees shall be aware of ethical values accepted in the entity and observe it while performing entrusted tasks. Managing personnel shall support and promote observing ethical values providing good example in daily behavior and taken decisions ${ }^{4}$.

- Effectiveness and efficiency of information flow (information and communication). Managing personnel and employees shall have the access to necessary information for performing duties. Effective system of communication shall allow the flow of information within the entity both horizontally and vertically and its proper understanding by recipients. Proper and reliable information shall be provided in due time while performing tasks, effective mechanisms of transmitting important information within the organizational structure of the entity and within the department of governmental administration and departments (internal communication), and effective system of sharing important information with external entities having the influence on achieving purposes and tasks completion (external communication).

- Risk management (purposes and risk management), which is intended to increase the probability and tasks completion. The process of risk management shall be documented.

One of the purpose of the management control is to provide the efficiency and effectiveness of the operations. The organization operates effectively when it attains assumed purposes. Both at strategic and operational level. Proper understanding of pur-

\footnotetext{
${ }^{4}$ With consideration of, that is, mandatory ethical codes, quality certificates acc. to ISO standards, etc.
} 
poses by employees and the involvement are beneficial to it effective completion.

The management sciences also include the method of management by objectives. The idea is based on the assumption saying that effective management shall direct the vision and effort of all management staff in order to achieve common goal (P.F. Ducker, 1992).

\section{Research methods}

The self-evaluation survey is used for the assessment of the phases of management control completion according to standards.

According to S. Kałużny, the self-assessment covers lots of possibilities in the range of the improvement of the operations quality, because it reveals the faults and eliminates it immediately, and it is its basic benefit (S. Kałużny, T. Zawadzka, 1999, p. 52). The surveys are simple and fast source of information, that is why when the manager wants to get the data on the control mechanisms in the entity, the self-assessment survey is the great source to obtain such information. Based on the results of the selfassessment, the signals on the adequacy and efficiency of the control mechanisms are obtained. It presents the variations and points out the scope and range of variations in the entity.

The self-assessment process inspires employees for the observation of processes, drawing conclusions of bureaucratic schema and this allows to get added value in the form of useful information. The information obtained in this way are a source of motivating employees and indicating the role of the management control in the entity.

The self-assessment is an inseparable element of management process - planning, deciding, organizing, performing, and controlling the process. It allows to quickly get information on weaknesses of control mechanisms, cumulating of gaps in decisive and executive processes, as a consequence, it makes the management more difficult and often generates cost. The assessment of management control allows to obtain information on the efficiency and adequacy of procedures, regulations, manuals, and other directives, especially in the areas where no audit or control operations were done. It shall be emphasized that the self-assessment is the next tool used to make self-assessment while functioning the entity and control mechanisms.

In the justification to the Announcement no. 3 of the Ministry of Finance of 16 February 2011 concerning the self-assessment of management control for the department of the public finance, the self-assessment is defined as the process in which the assessment of management control functioning is done by employees and managers of the entity (Announcement no. 3 of the Minister of Finance Dz. Urz. MF no. 2, item 11).

Main core of research was based on the data included in the survey questionnaire answers of managers and employees survey questionnaires.

Questions in the self-assessment survey were closedend questions, as it provide more detailed picture and clear confirmation of the facts. Besides, a person who is a subject of the close-end question is more trusting as this form provides better anonymity.

\section{$4 \quad$ Analysis of research results}

The management control in the department of public finance covers five groups of the problems, that is, internal environment, purposes and risk management, control mechanisms, information and communication, monitoring, and assessment. The catalog of purposes and management control is opened and requires definition by the manager of the entity of the public finance of additional purposes of the entity, considering its specifics, subject of the operations, and conditions of functioning of the entity (L. Lipiec-Warzecha, 2011).

Within the scope of these five purposes, the test in the form of questionnaires of self-assessment in the departments of fiscal sector.

Practical application of mentioned methods required to collect data concerning basic processes realized in Offices, or even the reasons of disturbances of its completion. Numerical expression of these defects required data collection to facilitate the estimation of basic indexes in the scope of basic processes completion. 


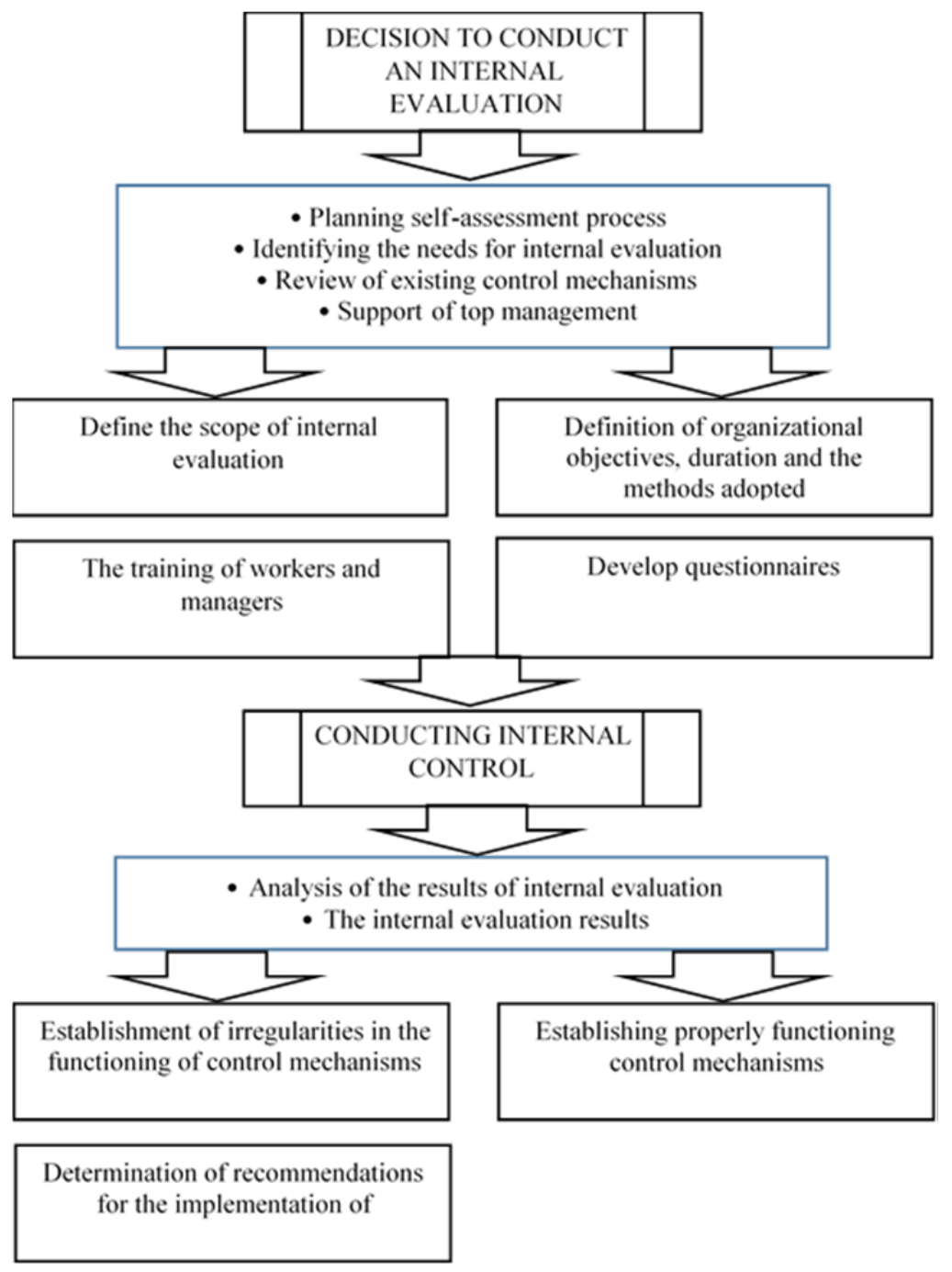

Figure 1. Phases of the self-assessment TCO (source: own work based on conducted research)

Data collection concerning the most important processes require obtaining data from Treasury Control Offices (TCO) on basic areas of its functioning as follows: process of internal environment, indicating purposes, tasks identification, and analysis of risk factors connected with achieving purposes and mitigation of risk, monitoring and control process, and information and communication process (Fig. 1).

Based on the conducted analysis, the following processes were determined, and within the Framework of it, the subprocesses have been specified; it was the subject of detailed research as far as the tasks of Treasury Control Offices are concerned, and it is as follows:

- internal environment,

- purposes and risk management,
- control mechanisms,

- information and communication,

- monitoring and assessment.

In the scope of the internal environment range, the research was conducted in the following subject range: construction of organizational structure and the tasks distribution on right persons. In terms of organizational structure construction, verify the followings:

- construction of proper organizational structure,

- adaptation of organizational structure to current purposes,

- adaptation of organizational structure to current tasks,

- include in organizational structure all necessary organizational units. 


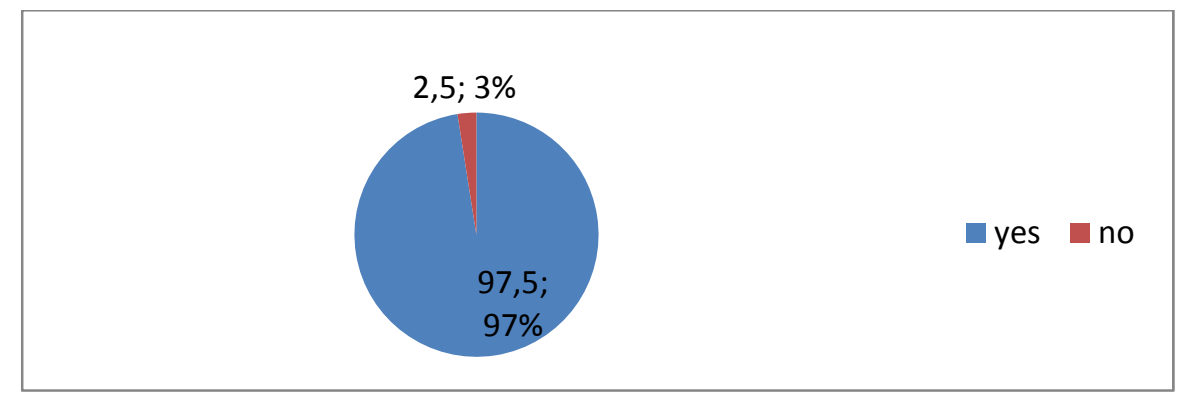

Figure 2. Analysis of tasks distribution in the scope of organizational structure of the entity selected out of results

(source: own work based on the self-assessment results)

When the self-assessment surveys are analyzed, it shall be stated that in the respondent evaluation of the population of management staff, the organizational structure in Treasury Control Offices is proper and does not require changes.

Almost all respondents ( $95 \%$ of interviewee) pointed that functioning organizational structure is adopted to current purposes and tasks assigned to the Treasury Control Offices. It shall be stated that management personnel is familiarized with the organizational structure, purposes, and tasks assigned to the Treasury Control Offices by General Inspector of Fiscal Control.

In terms of respondents out of employee group, situation looks much worse. The organizational structure of the Treasury Control Offices is known by $80 \%$ of interviewee but is assessed properly by $65 \%$; however, it is perceived as improper by $12 \%$ of interviewee. For comparison purpose, it shall be stated that $25 \%$ of interviewee pointed that the structure should be changed. Part of interviewee, despite that assess the structure as proper, awaits for changes. Three-fourth of interviewee are convinced that the structure is adopted to purposes and tasks of the Treasury Control Offices assigned by General Inspector of Fiscal Control. Twenty-five percent of interviewee states that they do not know if the structure is proper and if the structure requires changes, and the same amount states that they do not know if it is adopted to current purposes and tasks of the Treasury Control Offices. Results for managers are summarized in the chart - Fig. 2.

In the view of respondents of the population of management personnel and employees in the scope of organizational structure exists the discrepancy.
Part of employees is not informed enough in this field.

Almost the same percentage of the population of management personnel and employees admit that the scope of tasks is consistent with the scope of performed work. Approximately 5\% of interviewee from both groups is not consistent with the scope of tasks on an average. All respondents from the group of managers indicated that purposes assigned to be realized by the Treasury Control Offices are properly distributed into organizational units. In the event of interviewees, $75 \%$ of employees know purposes and tasks of the Treasury Control Offices that are translated into purposes and tasks of organizational units, and already $94 \%$ assesses it as properly distributed into organizational units (despite over $20 \%$ actually do not know it).

The organizational structure in all Treasury Control Offices is the same, and the scope of task assigned on organizational units is imposed a priori on the Treasury Control Offices with the status. Besides, all Treasury Control Offices have purposes and tasks that are posed by General Inspector of Fiscal Control every year, and they are accounted for it systematically. In connection with the above, considering the fact that managing Staff knows the structure, purposes, and tasks, and the Treasury Control Offices exists the hierarchy structure, it shall familiarize subordinate employees with purposes and tasks assigned to them, as employees are responsible for performing it. Such discrepancy of responses can result out of not understanding the essence of purposes by employees, as its content is the Treasury Control Office, it is widely available and it is uploaded into the Treasury Control Offices intranet websites. 


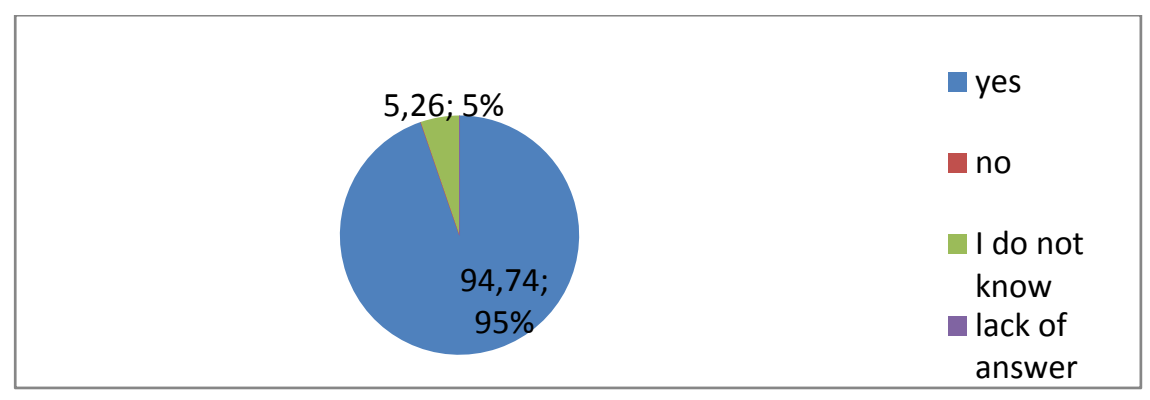

Figure 3. Analysis of identified purposes and tasks of the entity - selected out of obtained results (source: own work based on self-assessment results)

The organizational structure is implemented with organizational statue, which shall be ready by every employee and this fact shall be stated by the signature, and the document confirming it shall be entered into personal records of an employee.

The organizational structure, over the past five years, are not a subject of the change, the same units and assigned unchanged tasks.

Despite this fact, almost all employees point that tasks assigned to the Treasury Control Offices are properly distributed into organizational units.

While analyzing the risk factors identified in relation to the subprocess, it shall be stated that it is actually eliminated, as the organizational structure is properly implemented and adopted to current purposes and tasks of the Treasury Control offices, the level of tasks completion and attained purposes by the Treasury Control Offices in given year can certify that.

Summing up, it determined that the structure is organic in all Treasury Control Offices. It is consistent with the statue and implemented with the organizational rulebook.

In subject-matter scope, it verified the determination of purposes and tasks of the entity in the following range:

- minuteness of purposes definition,

- minuteness of the definition of entities tasks,

- determining the meters of tasks completion,

- proper distribution of tasks into given units (according to organizational structure),

- verification of even tasks distribution on employees (excessive amount of tasks, too small amount of tasks).
When the analysis is completed, it shall be stated that the whole surveyed population of management staff indicated that in the Treasury Control Offices, the purposes and tasks of the entities in annual perspective are clearly determined, one-fourth of the surveyed employees indicated that they do not know if the purposes or tasks are determined in annual perspective for the Treasury Control Offices.

All surveyed population of management staff indicated that they are familiarized with purposes and tasks of the Treasury Control Office on a given year. The reflection is included in the question on the familiarization with the mission, purposes, and tasks that are effective in the Treasury Control Offices. Besides, all surveyed personnel in this Group indicated that they conduct the monitoring of achieving purposes and the realization of tasks assigned to the Treasury Control Officer for the completion. Threefourth of the surveyed employees presented that they know the purposes and tasks for completion in a given year, one-fourth of surveyed indicated that they does not know it; however, $95 \%$ of surveyed declares that they monitor it. The results are presented in Fig. 3.

The identification and the analysis of risk factors in the entities was verified based on the following information:

- methods of identification and the familiarization of personnel obliged for its completion is set forth properly,

- proper determination of tasks for completion,

- identified all risk factors in relation to realized entity tasks,

- the process of identification of risk factors of the entity conducted properly, 


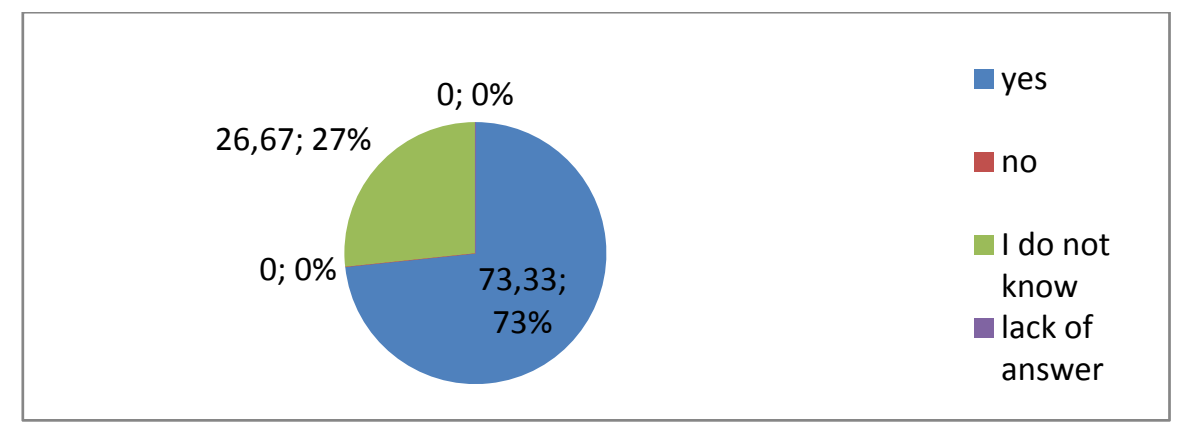

Figure. 4. Analysis of identification process and analysis of risk factors in the entity in relation to established purposes and tasks - selected out of research results (source: own work based on the self-assessment result)

- identified all risk factors of the entity,

- identification of risk factors was conducted by proper personnel,

- documentation out of risk factors is available,

- employees were familiarized with the identification of risk factors of the entity.

Based on the analysis of the self-assessment surveys, it shall be stated that in the Treasury Control Offices in relation to determined purposes and tasks, risk factors influencing the achievements of strategic and operational purposes by the entity are identified. The process of risk factors identification is extremely important.

The analysis of surveys show that the whole group of respondents of the management staff do not know what is the process of risk identification and what method of risk identification in the Treasury Control offices shall be applied. In terms of respondent originating out of employees group, it shall be indicated that only almost half of the surveyed know what method was applied.

The analysis of respondents answers of management staff presents that in the Treasury Control Offices, all risks were identified. Within the framework of determining how often the process is conducted show that at least once a year, and in the following year while specifying more details, $90 \%$ stated that once in a year and every $5 \%$ that once a quarter and once a month.

In terms of respondents of employees group, it shall be pointed that it is possible that employees did not understand the question or gave wrong answers. Namely, in the scope of previous question - if they identified all risks - it determined that $40 \%$ of the surveyed personnel do not know, and within the framework of question, if the risk factors were identified, almost three-fourth answered yes. For almost half of the respondents, the determination of the frequency of the process of the identification of risk factors in the Office also is problematic. Forty percent of employees indicated the frequency - once a quarter and once a month. The results are presented in Fig. 4.

The process of risk identification is one of the element of risk management system. All respondents from the group of management personnel indicated that the system of risk management is documented in the Treasury Control Offices and is available for everyone, but merely over $80 \%$ of surveyed pointed that they are familiarized with the documentation. However, in the group of employees, almost half of surveyed pointed that they do not know about the documentation on the system of risk management, and in the following year, almost $80 \%$ points that they are familiarized with the documentation of risk management system.

The issue concerning who familiarized with the documentation in the question was addressed for all together $-2 / 5$ of the surveyed indicated that they are familiarized with it on their own, 1/5 through the manager (in terms of management personnel it was the Director).

The process of the identification of risk management is one of the element of the process of risk management in the Treasury Control Office. The identification of risk factors shall refer to identified or determined strategic and operational purposes of the Treasury Control offices each time. 


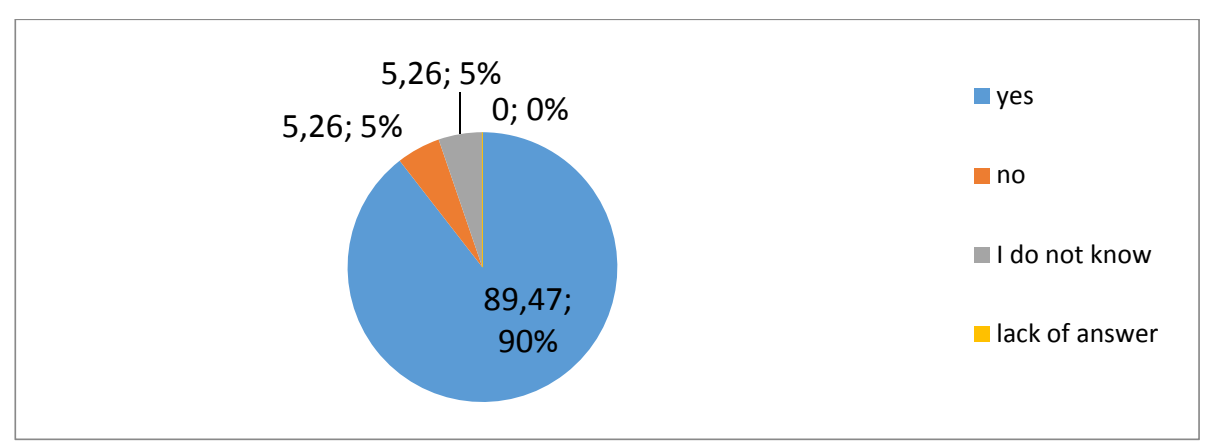

Figure 5. Analysis of control mechanisms in the scope of financial procedures - selected out of research results (source: own work based on self-assessment results)

That is why, the process of the identification of risk factors is a starting point for further analysis of risk and when it is wrongly done (using, e.g., improper method of risk identification) can be a reason of not reaching strategic and operational purposes by the Treasury Control Offices. In the Treasury Control Offices, the method and frequency of the identification of risk factors of the entity were determined. The process of identifying risk shall be done by all managers; moreover, they shall agree with employees existing risk factors - came across while completing tasks. Based on the determined risk factors, the register of risk factors is constructed. The identification and risk analysis is conducted once a year. If some risk factors are influencing strategic and operational operations, the register is supplemented through the year. The whole process of risk identification is documented. Final effect in the form of the register of risk factors is entered with the instruction of the Director of the Treasury Control Office. The management staff is supposed to familiarize employees with the register of risk factors. Besides, the register of risk factors is published on intranet website of the Treasury Control Office.

The research presented that the subprocess of risk factors is not protected and requires remedy actions:

- internal training for employees in the scope of identification and analysis of risk factors,

- increase of the supervision of managers over tasks completion,

- increasing the supervision over the employees by the team dealing with the management control,

- increasing of the control element of management personnel,
- involving employees into the identification and analysis of risk factors in the Treasury Control Offices.

In the scope of the following areas, control mechanisms, analysis concerned identified control mechanisms with functioning financial procedures and those connected with IT systems in the scope of tasks completion concerning the System of Information Safety Systems. Within the framework of control mechanisms focused on financial procedures, the following are assessed:

- determined accountancy principles,

- defined precisely accountency principles,

- determined the accountancy principles in procedures,

- indicated responsible personnel in the accountancy principles,

- indicated scope of tasks and responsibility of personnel in the accountancy principles.

Upon the self-assessment questionnaires, within analyzed period, it shall be stated that approximately $90 \%$ of surveyed managers and approximately $75 \%$ of surveyed employees pointed that in the Treasury Control Offices, functions formal principles on the control and workflow of documentation connected financial and economy operations including public procurement. The same population stated that it is a reliable and consistent operation.

Approximately $75 \%$ of managers and $65 \%$ of employees pointed that in the documentation concerning financial and economy operations, key responsebilities are distributed into various personnel. The results are presented in Fig. 5. 


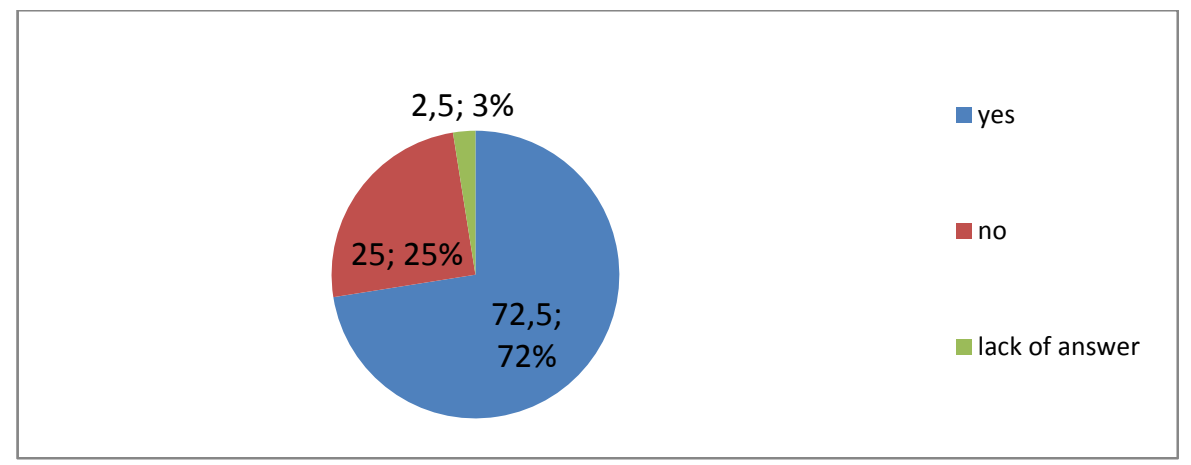

Figure 6. Analysis of functioning control mechanisms in the scope of IT systems - selected out of research results (source: own work based on self-assessment results)

All managers and approximately $85 \%$ of employees pointed that in the Treasury Control Offices, mechanisms for providing personal details safety and IT systems exist.

The same population, that is $95 \%$ of surveyed managers and $85 \%$ of surveyed employees indicated that in the Treasury Control Offices implemented technical solutions shall provide safe processing of data in IT systems.

The accountancy principles, scope of financial and economy operations, workflow of financial and record keeping documents, and granting public procurements are prepared in the Treasury Control Offices. While completion of these tasks not only employees of accountancy unit participate but also all other employees, that is, in the scope of using company's vehicles, using private vehicles for company's interest, settling delegations, and applications on minor purchases, materials, and books. This topic, in the scope if interest, shall be widely known for all employees as they participate in the documentation workflow. Presenting unfamiliarity of this topic by employees and weak results of internal control in this scope certify on some problems in completing these tasks. The instruction of the director in this scope are available on the intranet website of the Treasury Control Office, managers are familiarized with the documents and are obliged to familiarized with it subordinate employees. In this situation, training for all employees seems to be a must. In terms of responsibility for financial economy indicated proper personnel, they are responsible for financial assets, performing initial control, and formal and accounting control and others.
The scope of responsibilities of employees is determined in the documentation and additional authorities. Identified risk factors are not minimized to accepted level, that is why the remedy actions are necessary.

The subprocess is not protected and requires the following remedy actions: in terms of mechanisms of financial and economy operations - training conducted by chief accountant in the scope of accepted solutions for finance and economy in the Treasury Control Office, public procurement, and taskoriented budget.

The assessment of procedures connected with functional IT system was done considering the following:

- determining the scope of personal details safety,

- observing personal details safety,

- determining protecting data in IT systems,

- implementing proper protection of data in IT systems.

Based on the results of the self-assessment surveys, it shall be stated that all mangers and approximately $85 \%$ of employees indicated that in the Treasury Control Offices, mechanisms for personal details safety and IT systems exist.

The same population, that is, $95 \%$ of the surveyed managers and $85 \%$ of the surveyed employees, pointed that in the Treasury Control Offices, implemented technical and organizational solutions provide safe processing of data and operate in IT systems.

Seventy-two percent of the surveyed know the procedures and instructions in the scope of IT systems. 


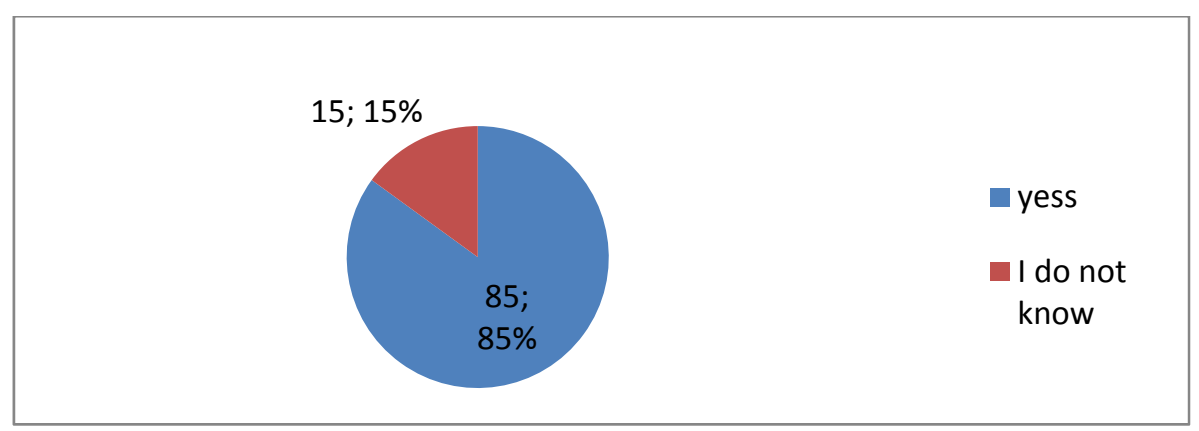

Figure 7. Analysis if information process in the entity - selected out of research results (source: own work based on self-assessment result)

The fact that over $25 \%$ of surveyed do not know the procedures, despite the fact that they perform it every day based on IT system, is a reason for disconcerting (Fig. 6).

However, the continuity of operation was provided. In terms of the systems safety, it prepared the part of documentation in the following form: instruction for IT systems management, safety policy for data. Implemented safe login for computer - access password for computer, access codes for electronic mail, and installed antivirus programs - filters for entry on websites. Principles of using IT equipment were determined in Director's instruction and all employees were familiarized with it, all regulations are available on the website.

Identified risk factors are not minimized to accepted level, that is why remedy actions are required. The policy for information safety, declaration of using it and other information for distribution and transfer it, including personal details are under continuous consideration.

Proposed remedy action in terms of IT mechanisms shall cover preparing missing documentation in terms of IT management system for information safety, safe information policy, declaration of using it, update of missing data in terms of the manual of IT system management, personal details safety policy, authorities for processing personal details, and training of employees and managers.

In the scope information and communication, the research of surveys concerned the information process and internal communication in entities.
The following are verified in terms of information process:

- determined proper communication systems in the entity,

- constructed the internal communication system properly,

- provided an access to proper information necessary to tasks completion for managers and employees.

The self-assessment survey determined that $85 \%$ of surveyed managers and $60 \%$ of employees pointed that in the Treasury Control Office, effective mechanisms of distributing important data in horizontal and vertical data are provided. All surveyed managers and $65 \%$ of surveyed employees pointed that mechanisms of distributing important information horizontally and vertically are sufficient to safe the system. Twenty percent of employees and $10 \%$ of managers pointed that formal barriers influencing adversely in information distribution in horizontal and vertical distribution exist (Fig. 7).

Over $95 \%$ of surveyed employees and managers pointed that the access to the information to tasks completion is necessary. That is why it shall be stated that employees and managers has the access to the intranet website and internal documentation.

In the Treasury Control Offices, the communication channel is represented in terms of formal hierarchy functions: the communication channel managing personnel - managers of organizational units, communication channel of organizational units and employees. 


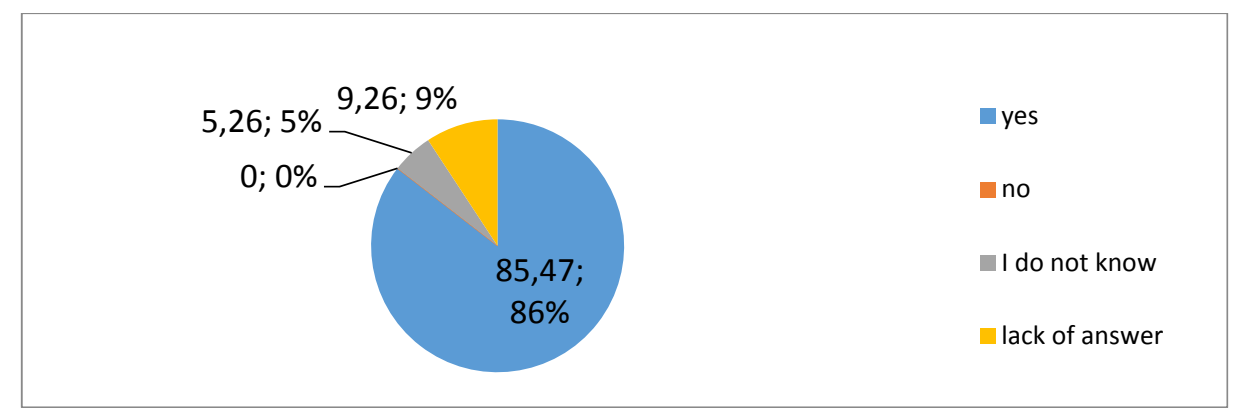

Figure 8. Analysis of communication process in the entity - selected out of research results (source: own work based on the self-assessment results)

From the scope of distributed data, its scrutiny and timeliness depends on the level of tasks completion by employees. Every two weeks managing personnel council and managers takes place, where meters of tasks and purposes completion assigned to some organizational units are analyzed. Distributing information among managers and employees is done without any problems, because of all unclear tasks assigned to employees. Tasks assigned to employees both in written and oral form is various. The level of tasks completion by some employees is also various. Employees do not understand the concept and scope of questions.

The risk analysis indicated that the system is implemented and risk factors are minimized.

While assessing internal communication in entities, consider the following:

- determined proper communication system with external entities,

- constructed the system of external communication properly,

- constructed the image of fiscal control properly,

- current and reliable information on the entity operations are distributed and made available.

The self-assessment surveys determined that over $95 \%$ of surveyed managers indicated that in the Treasury Control Offices, communication channels with external entities are constructed. In terms of employees, effective functioning of channel indicated only half of surveyed.

In terms of external communication, both employees and managers do not analyze the Public Information Bulletin (BIP) as almost three-fourth of surveyed indicated they that do not know if information are updated. Hundred percent of managers and over half of employees stated that media presentation of the Treasury Control Office is conducted in sufficient level (assuming that $3 / 5$ answered I do not know). The results are presented in Fig. 8.

In the Treasury Control Office, the scope of communication system functioning with external entities are determined. For the purpose of distributing information with external entities, for example, taxpayer, is authorized an employee running this case, unit manager - while explaining, Vice-director/Director. For media contact, spokesperson and the Treasury Control Office Director. For the purpose of contact external controllers, the Director of the Treasury Control office and internal auditor in the scope indicated in the authorization.

In the PIB are published the information concerning the recruitment process - announcements on vacancies, letters of inquiry - tenders, plans of operations and reports on its completion, statements on the management control - in the scope of management control, results of external control, and other cases, which can concern taxpayers.

The risk analysis presented that the system is implemented, and risk factors are minimized.

The assessment of tasks realization monitoring concerned the information verification and

- determined proper process of monitoring,

- determined that the monitoring process refers to purposes and tasks,

- determined that tasks are realized on time and according to regulations,

- determined that tasks are adopted to the organizational structure, 


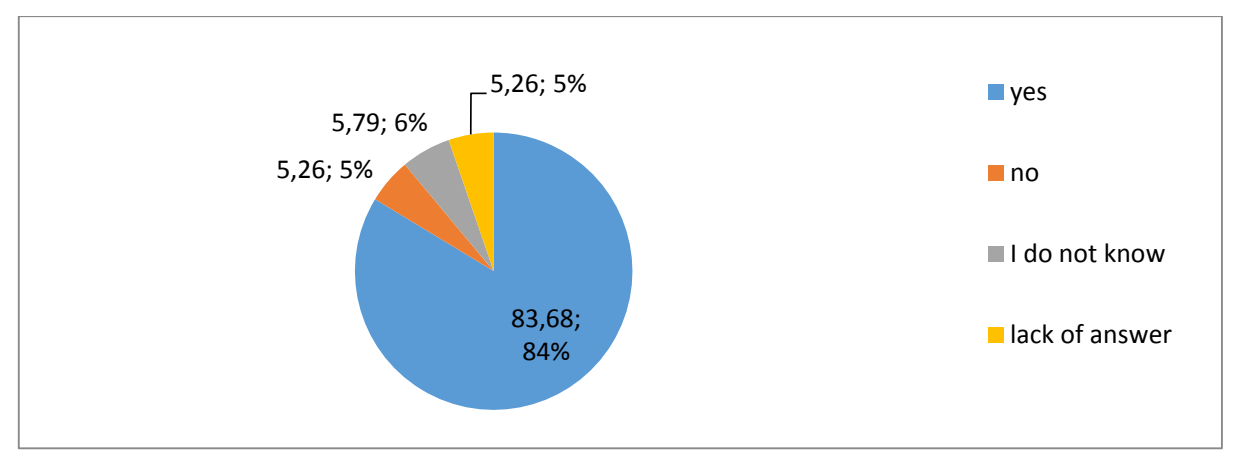

Figure 9. Analysis of the assessment of monitoring of purposes and tasks in the entity selected out of research results

(source: own work based on self-assessment results)

- determined that risk factors refer to purposes and tasks identified in entities,

- determined if the monitoring process of purposes and tasks completion in the entity is protected.

Based on the results of self-assessment, it shall be stated that over $85 \%$ of surveyed personnel know what are the purposes and tasks in entities for completion in a given year.

All respondents from management personnel indicated that purposes and tasks are defined, all confirmed that the monitoring is done with meters and with the consideration of economy, effectiveness, and efficiency criterion. They also indicated that in the Treasury Control Offices, the assessment of tasks is performed. Besides, almost the whole population indicated that the tasks completion is done in an economic, effective, and efficient way. Seventy-five percent of respondents from employees group indicated that in the Treasury Control Offices, the purposes and tasks are determined, and it shall be stated that it is known for them.

Only half of respondents indicated that purposes and tasks are monitored with meters with the consideration of eco-nomy, effectiveness, and efficiency criterion. It does not change the fact that the same population confirmed that performing tasks of the Treasury Control Office is carried out in an economic, effective, and efficient way, 2/5 surveyed stated that they do not know if the monitoring of purposes and tasks completion or such monitoring exists. Surprising is the fact that over $1 / 5$ surveyed stated that tasks completion is not carried out economically, effectively, and on time (Fig. 9).
Purposes and tasks for completion by the Treasury Control Office were determined in the entity. The management personnel familiarized with it and the monitoring is done. The analysis of the documentation indicates that employees do not have the consciousness of what are the purposes and tasks, what is the importance of it, and the entity's manager is assessed. Besides, the aspect of tasks completion in the Treasury Control Offices is important.

The management control is supposed to provide the tasks completion effectively, efficiently, and on time while spending as little financial assets as possible. It is visible that employees know the subject matter of indicating and analysis of purposes and tasks of the Treasury Control Offices. The analysis reveals that the tasks are not distributed into organizational units or employees were not familiarized with it.

The method of realization determined and defined purposes and tasks in the Treasury Control Offices is important. Proper distribution of purposes and tasks into organizational units and timely and efficient assessment of management personnel in terms of assigned tasks influences on the quality and timeliness of tasks completion. Lack of indicating meters is a reason of tasks realized not on time, not enough amount, and extensive cost.

Employees do not know determined meters and it is a reason that employees perform tasks without economy, effectiveness, efficiency criterion. In this way, it increases the cost of Treasury Control Offices functioning, do not include expected income to the budget. 
Upon the risk analysis, it shall be stated that the level of risk is high, employees shall know determined purposes and tasks, and it is assigned in such a way that to perform effectively and on time.

It shall be stated that implementation control mechanisms that are supposed to increase the supervision over Directors and managers, providing permanent element of supervision over managers and employees and specifying the purposes and tasks assigned to the Treasury Control Offices for a given year and familiarization of employees and training.

The subprocess is not protected and requires remedy actions:

- internal training for employees in the scope of determining meters for purposes and tasks,

- increase of the supervision of managers over the tasks completion,

- increase of the supervision over employees by the management personnel team,

- increase of control element of management personnel,

- identification of risk factors in relation to purposes and tasks of the Treasury Control Offices.

\section{Conclusions}

The assessment of some elements of the management control in the Treasury Control Offices is important for involved, and from the economy point of view, and first of all for the budget. It shall be performed within the framework of assigned purposes based on well-built model and within the scope of all management levels.

The assessment was done in terms of processes, subprocesses, tasks, and subtasks to verify functioning of management areas and provide the following: conformity of operations with legal regulations and internal procedure, efficiency and effectiveness of operations, credibility of reports, resources protection, observing and promoting rules of ethical behavior, effectiveness and efficiency of information flow, proper management of risk management, and assessment of the completion of some elements of management control.

Each process refers to the management element, and its purpose is to Support the Director of the
Treasury Control Office in the management process and providing the quality of functioning of the Treasury Control Office in the area of operation. The implementation and assessment of the management control of department of fiscal sector contributes, among others, to the following:

- determining in entities rules and components of effective process of risk management and determining the method of identifying, assessing, reacting, and controling all important types of risk identified in entities,

- Provides "common language", so that the managerial personnel, managers, and others saying about the risk management could communicate well (providing proper internal and external communication),

- determining the way the entity uses risk management in strategic planning, describes techniques of identification and risk management,

- emphasizing if the process of risk management identifies not only negative aspects but also positive aspects or possibilities that can be used to improve capabilities and values of the entity,

- determining main roles of participants of the process of risk management in entities,

- verification of internal regulations in the entity and making an update,

- training for employees in the scope of the identification and analysis of risk factors, IT systems, and procedures of financial control.

The risk management is not a one time, prepared for only a single moment act or group of decisions, but extended in time complex decision process. The management control has added value for the highest management of the company and employees. First of all, it prepared entities for definite threat in real life.

The entity, in which the process of risk management is carried out effectively, has prepared methods for minimization of the threat and its results. Summing up, it contributes to great increase in the competitiveness.

The fact of existing and the quality of running risk management with effective system of risk management is, according to specialists, a benchmark of the maturity and culture of the entity. Superior purpose 
of the risk management is the protection and optimization of the entity value: its assets, cash flow, operational capability, participation in the market. The risk connected with the entity cannot be avoided; however, it shall be taken consciously through effective management of processes connected with management control.

The management control is developing, and the management personnel got started to understand its significance. It shall allow to better use of financial assets and resources that are at the disposal in every organization of public finance sector. For certain well-applied analysis of risk factors in the scope of risk management which is an element of management control shall allow to identify most of areas of the risk of the entity and provide its proper functioning. It shall be stated that effective and efficient system of management control contributes to effective completion of statue tasks and general improvement of the entity operations.

\section{$6 \quad$ References}

[1] Barney D. (2008) - Społeczeństwo sieci. Wydawnictwo Sic!, Warszawa 2008.

[2] Chojna-Duch E. - Podstawy finansów publicznych i prawa finansowego. Warszawa 2011.

[3] Ducker P.F. - Praktyka zarzadzania. Wyd. Ekonomiczne, Kraków 1992.

[4] Griffin R.W. - Podstawy zarzadzania organizacjami. Wydawnictwo Naukowe PWN Warszawa 2010.

[5] Griffin R.W. - Podstawy zarzqdzania organizacjami. Wydawnictwo Naukowe PWN, Warszawa 1998.

[6] Kuc B.R. - Kontroling narzędzie wczesnego ostrzegania.Wydawnictwo Menedżerskie PTM, Warszawa 2006.
[7] Kałużny S., Zawadzka T. - Kontrola gospodarcza $w$ jednostkach budżetowych. Warszawa 1999.

[8] Lipiec-Warzecha L. - Ustawa o finansach publicznych. Komentarz, Wolters Kluwers Polska, Warszawa 2011.

[9] Nowak E. - Zawansowana rachunkowość zarzadcza, PWE Warszawa 2003.

[10] Puchacz K. - Nowa ustawa o finansach publicznych, Gdańsk 2009.

[11] Robbins S.P., DeCenzo D.A. - Podstawy zarzqdzania, PWE, Warszawa 2002.

[12] INTOSAI, Standardy kontroli wydane przez Komisję Standardów Kontroli Międzynarodowej Organizacji Najwyższych Organów Kontroli, NIK, Warszawa 2000.

[13] Rozporządzenia Rady (WE, EURATOM) nr $1605 / 2002$ z dnia 25 czerwca 2002 r. w sprawie rozporządzenia finansowego mającego zastosowanie do budżetu ogólnego Wspólnot Europejskich - art. 27 (Dz.U. L 248 z 16.09.2002, s. 1)

[14] Komunikat nr 23 Ministra Finansów z dnia 16 grudnia 2009 r. w s sprawie standardów kontroli zarządczej dla jednostek sektora finansów publicznych (Dz. Urz. MF Nr 15, poz. 84).

[15] Komunikatu Nr 3 Ministra Finansów z 16 lutego 2011 r. w sprawie szczegółowych wytycznych w zakresie samooceny kontroli zarządczej dla jednostek sektora finansów publicznych (Dz. Urz. MF Nr 2, poz. 11).

[16] Komunikat Nr 6 Ministra Finansów z dnia 12 kwietnia $2010 \mathrm{r}$. w sprawie standardów definiowania celów dla jednostek sektora finansów publicznych w zadaniowym planie wydatków na rok 2011 (Dz. Urz. MF Nr 5, poz. 22).

[17] http://www.wneiz.pl/nauka_wneiz/frfu/532012/FRFU-53-11.pdf. 